Published with Open Access at Journal BiNET

Vol. 02, Issue 02: 118-124

International

Journal BiNET

Journal of Business, Management and Social Research

Home page: www.journalbinet.com/ijbmsr-journal.html

\title{
Postharvest loss assessment of brinjal in some selected areas of Bangladesh
}

\author{
M. I. Kaysar ${ }^{1}$, M. S. Mia ${ }^{2}$, M. S. Islam ${ }^{3}$ and A. K. M. G. Kausar ${ }^{4}$ \\ ${ }^{1}$ Agricultural Economics Division, Bangladesh Agricultural Research Institute (BARI), Gazipur-1701 \\ ${ }^{2}$ Monitoring Division, Bangladesh Agricultural Development Corporation (BADC), Dhaka-1000 \\ ${ }^{3}$ Agricultural Economics Division, Bangladesh Sugarcrop Research Institute (BSRI), Ishwardi-6621 \\ ${ }^{4}$ Dept. of Agribusiness Management, EXIM Bank Agricultural University Bangladesh, Chapainawabganj- \\ 6300, Bangladesh
}

\begin{abstract}
The study was conducted in three districts namely Narshingdi, Jessore and Bogra to assess the postharvest losses of brinjal. Multistage sampling technique has been used for selection of 90 brinjal growers and intermediaries, out of which 15 farmers and 15 intermediaries from each district selected randomly. Both descriptive and inferential statistics were used to calculate the postharvest losses of brinjal at different stages and determine the factors responsible of postharvest losses of brinjal at farmer level; a multiple linear regression model was carried. Total postharvest losses of brinjal were estimated by taking total losses at farmer, Aratdar, Bepari and retail level. A total postharvest loss of brinjal was $23.38 \%$. Highest loss was estimated that $12.51 \%$ at the grower level. Among different intermediaries post harvest loss of brinjal was highest at retail level (5.96\%) than Aratdar level losses (2.35\%) and Bepari level losses (2.65\%). Farming experience, sale price, transportation had negative and total production and weather had positive and significant relationship with the total postharvest loss of vegetable. Absence of postharvest treatments, low market price, lack of available storage facilities, and poor and costly transportation were the major problems at farm and intermediaries level. Proper storage facilities, easy transportation, applied scientific method of harvesting and fair price policy suggested by the study to minimize the postharvest loss.
\end{abstract}

Key Words: Brinjal, Postharvest loss, Assessment, Market loss, Growers and Storage

Please cite this article as: Kaysar, M. I., Mia, M. S., Islam, M. S. \& Kausar, A. K. M. G. (2016). Postharvest loss assessment of brinjal in some selected areas of Bangladesh. International Journal of Business, Management and Social Research, 02(02), 118-124.

This article is distributed under terms of a Creative Common Attribution 4.0 International License.

\section{Introduction}

Bangladesh is an agriculture based country which produces a lot of fruit and vegetables apart from staple food rice. Fresh vegetables are very much important for diet mainly for vitamins, minerals and antioxidants. To meet the requirement of vast number of people's demand of vegetables it is needed to 
reduce postharvest loss. For a human body minimum requirement of fruit and vegetables 400 gm/day/capita (FAO, 2003) but the present consumption of fruits and vegetables in Bangladesh is only 211 gm/day (fruits, brinjal and potato). In Bangladesh favorable climatic conditions variety of vegetables are grown. Presently, Bangladesh has produced 10931 thousand metric tons of vegetables per year (BBS, 2011). The commercially important vegetables include potato, tomato, brinjal, cabbage, cauliflower, bitter gourd, pointed gourd, spinach, Indian spinach, beans, radish, carrots, cucurbits, and plantains etc. In marketing aspect research in post harvest activities specifically prevention of losses at different stakeholder level will provide valuable information and guideline for loss reducing activities, as a result it increases benefits by the increase of quality and prices. To maintain vegetable quality at different levels postharvest operations like harvesting, sorting, grading, packaging, loading, unloading, cooling and storage are hardly used in Bangladesh (Hassan, 2010). Recently, Hassan (2010) reported that a big proportion of the fruits and vegetables losses after harvest ranged from 23.6 to $43.5 \%$. Although the modern fruit and vegetable processing sector is growing, but still less than $1 \%$ of total horticultural production is currently processed. Although vegetables are consumed fresh every year huge amounts vegetables are spoiled in Bangladesh due to lack of proper postharvest management facilities. Postharvest losses of fresh fruits and vegetables of Bangladesh are about 25-50\% (Amiruzzaman, 1990), where it is only 5-25\% in developed countries (Kader, 1992). Brinjal are highly perishable in nature and they should be brought to the consuming as quickly as possible in order to satisfy the market requirement. Even the retailers should sell the produce as soon as possible to avoid qualitative and quantitative losses. Poor handling and marketing systems cause huge post-harvest losses of commodities during storage, transport, wholesaling and retailing, particularly when the conditions remain unfavorable and at one stage produce becomes unfit for marketing or human consumption. Thus, postharvest management of brinjal is important for the country for minimization of post harvest losses, nutritional improvement, food and financial security of the people and employment generation. To meet the demand of people it is quite necessary to reduce the postharvest losses as much as possible. Therefore, this study has been undertaken to estimate the postharvest losses of brinjal in production and marketing level, to identify the factors responsible for postharvest losses and to identify some measures to reduce the losses.

\section{Methodology}

Sampling technique: Studies were conducted in the Narshingdi, Bogra and Jessore district. Study was conducted brinjal intensive growing area in the view of potential for production, marketing and export of brinjal. Multistage sampling technique was used for selection of brinjal farmers and intermediaries. 90 brinjal growing farmers and traders, out of which 15 farmers and 15 traders from each district were selected randomly. Five Aratder, five Bepari and five retailers from each district were selected randomly. In different locations data were collected using a pre-structured schedule by personal interview method. Data was collected during the months January to March in 2014.

Analytical technique: Postharvest loss of brinjal at different levels was calculated by using simple statistical tools like average, percentage in the different study areas.

Postharvest loss of brinjal is likely influenced by different factors. The following Cobb-Douglas type function was used to estimate the parameters. The function of the Cobb-Douglas multiple regression equation was as follows:

$$
\begin{aligned}
& Y=a+b_{1} X_{1}+b_{2} X_{2}+b_{3} X_{3}+---------------b_{8} X_{8}+e \\
& \text { Where, } \\
& Y=\text { Postharvest losses of brinjal }(\mathrm{kg} / \mathrm{ha}) \\
& X_{1}=\text { Age (years) } \\
& X_{2}=\text { Education (year of schooling) } \\
& X_{3}=\text { Farming experience (years of brinjal cultivation) } \\
& X_{4}=\text { Total production }(\mathrm{kg}) \\
& \left.X_{5}=\text { Sale price of brinjal (Tk } / \mathrm{kg}\right)
\end{aligned}
$$


$\mathrm{X}_{6}=$ Transportation dummy if favourable 1 , otherwise ' 0 '

$\mathrm{X}_{7}=$ Weather dummy if favourable ' 1 ' otherwise ' 0 '

$\mathrm{a}=$ intercept

$b_{1}, b_{2}--------------------b_{7}=$ Coefficients of the respective variable

$\mathrm{e}=$ Random error

\section{Results and Discussion}

\section{Postharvest loss of brinjal at farm level}

Postharvest loss of brinjal is occurred from harvesting period to ultimate consumer level. In farmer level loss occurred due to insect damage, rotten damage, cleaning, storage and transportation period and in intermediaries level loss occurred mainly due to loading or unloading, transportation, storage, and selling time. Brinjal is perishable commodity thus they undergo a lot of physical, chemical and physiological changes during the whole process of harvesting, storage, handling, transportation and marketing, resulting in a deterioration of quality and loss in weight. Post-harvest losses of brinjal were incurred at both growers' and intermediaries' level. On an average, the post-harvest loss of brinjal was $(12.51 \%)$ at farm level (Table 01). This loss was comparatively high in Jessore $(12.85 \%)$ and Bogra $(12.73 \%)$ than in Narsingdi (11.94\%). It was happened mainly due to local variety of brinjal, insect damage, and rotten damage, inappropriate method of grading and lack of favorable transportation facilities. It was found that harvesting loss (5.32\%) was highest in the study areas followed by grading loss (4.82\%), transportation loss (1.33\%).

Table 01. Average per hectare loss of brinjal at farmers' level

\begin{tabular}{|l|l|l|l|l|}
\hline Particulars & Narshingdi & Jessore & Bogra & Areas \\
\hline Production/ha & 62500 & 56300 & 58240 & 59013 \\
\hline 1. Harvesting loss & $3250(5.20)$ & $3040.20(5.40)$ & $3121(5.36)$ & $3137(5.32)$ \\
\hline \multicolumn{1}{|c|}{ a. Insect damage } & $2000(3.20)$ & $1824.12(3.24)$ & $1817.1(3.12)$ & $92.75(3.19)$ \\
\hline b. Rotten loss & $1250(2.00)$ & $1216.08(2.16)$ & $1304.58(2.24)$ & $66.86(2.13)$ \\
\hline 2. Cleaning loss & $400.00(0.64)$ & $337.80(0.60)$ & $361.09(0.62)$ & $366.30(0.62)$ \\
\hline 3.Grading loss & $2875.00(4.60)$ & $2758.70(4.90)$ & $2882.88(4.95)$ & $2838.86(4.82)$ \\
\hline 4. Other losses & $218.75(0.35)$ & $168.90(0.30)$ & $145.60(0.25)$ & $177.75(0.30)$ \\
\hline 5.Transportation loss & $718.75(1.15)$ & $844.50(1.50)$ & $786.24(1.35)$ & $783.16(1.33)$ \\
\hline \multicolumn{1}{|c|}{ a. Bruises } & $187.50(0.30)$ & $253.35(0.45)$ & $232.96(0.40)$ & $224.60(0.38)$ \\
\hline \multicolumn{1}{|c|}{ b. Damage } & $437.50(0.70)$ & $506.70(0.90)$ & $436.80(0.75)$ & $460.33(0.78)$ \\
\hline Totading or Unloading & $93.75(0.15)$ & $84.45(0.15)$ & $116.48(0.20)$ & $98.23(0.17)$ \\
\hline
\end{tabular}

Figures inside the parentheses indicate percentage loss of total production

\section{Postharvest loss of brinjal at intermediaries' level}

Post-harvest losses of brinjal at intermediaries' level were $10.87 \%$ of which $2.26 \%, 2.65 \%$ and $5.96 \%$ losses were occurred at the time of Aratder, Bepari and retailer level (Table 02, 03, and 04), respectively. Average loss of Aratder in all areas were occurred $1.21 \%, 0.50 \%$ and $0.55 \%$ for grading, storage, transportation and selling loss respectively (Table 02). Average loss of Beparies in all areas was occurred $1.08 \%, 0.50 \% 0.75 \%$ and $0.32 \%$ for grading, storage, transportation and selling loss respectively (Table 03). Retailer average loss of all areas was occurred $1.98 \%, 0.92 \%$ and $3.06 \%$ for grading, transportation and selling loss respectively (Table 04). 
Table 02. Postharvest loss in brinjal at Aratder level (Figures in quintals)

\begin{tabular}{|l|l|l|l|l|l|l|l|}
\hline \multirow{2}{*}{ Crop } & Districts & $\begin{array}{l}\text { Average } \\
\text { quantity } \\
\text { purchased }\end{array}$ & $\begin{array}{l}\text { Average } \\
\text { quantity } \\
\text { sold }\end{array}$ & $\begin{array}{l}\text { Grading, } \\
\text { packaging and } \\
\text { loading loss }\end{array}$ & $\begin{array}{l}\text { Transporta } \\
\text { tion loss }\end{array}$ & $\begin{array}{l}\text { Selling } \\
\text { loss }\end{array}$ & $\begin{array}{l}\text { Total } \\
\text { loss }\end{array}$ \\
\hline \multirow{4}{*}{ Brinjal } & Narsingdi & 8000 & 7839.20 & $92.80(1.16)$ & $\begin{array}{l}32.00 \\
(0.40)\end{array}$ & $\begin{array}{l}36.00 \\
(0.45)\end{array}$ & $\begin{array}{l}160.80 \\
(2.01)\end{array}$ \\
\cline { 2 - 8 } & Bogra & 6520 & 6364.82 & $81.50(1.25)$ & $\begin{array}{l}35.86 \\
(0.55)\end{array}$ & $\begin{array}{l}40.42 \\
(0.62)\end{array}$ & $\begin{array}{l}155.18 \\
(2.38)\end{array}$ \\
\cline { 2 - 8 } & Jessore & 7325 & 7152.86 & $89.37(1.22)$ & $\begin{array}{l}40.29 \\
(0.55)\end{array}$ & $\begin{array}{l}42.49 \\
(0.58)\end{array}$ & $\begin{array}{l}172.14 \\
(2.35)\end{array}$ \\
\cline { 2 - 8 } & All areas & 7281.67 & 7117.10 & $88.11(1.21)$ & $\begin{array}{l}36.41 \\
(0.50)\end{array}$ & $\begin{array}{l}40.05 \\
(0.55)\end{array}$ & $\begin{array}{l}164.57 \\
(2.26)\end{array}$ \\
\hline
\end{tabular}

Figures inside the parentheses indicate percentage loss of total quantity loss of vegetable.

Table 03. Postharvest loss in brinjal at Bepari level (Figures in quintals)

\begin{tabular}{|c|l|c|c|c|c|c|c|c|}
\hline Crop & Districts & $\begin{array}{c}\text { Avg. } \\
\text { quantity } \\
\text { purchase }\end{array}$ & $\begin{array}{c}\text { Avg. } \\
\text { quantity } \\
\text { sold }\end{array}$ & $\begin{array}{c}\text { Grading, } \\
\text { packaging } \\
\text { \& loading } \\
\text { loss }\end{array}$ & $\begin{array}{c}\text { Storage } \\
\text { loss }\end{array}$ & $\begin{array}{c}\text { Transpor } \\
\text {-tation } \\
\text { loss }\end{array}$ & $\begin{array}{c}\text { Selling } \\
\text { loss }\end{array}$ & $\begin{array}{c}\text { Total } \\
\text { loss }\end{array}$ \\
\hline \multirow{3}{*}{ Brinjal } & Norsingdi & 560 & 545.16 & $6.27(1.12)$ & $\begin{array}{c}2.97 \\
(0.53)\end{array}$ & $\begin{array}{c}3.81 \\
(0.68)\end{array}$ & $\begin{array}{c}1.79 \\
(0.32)\end{array}$ & $\begin{array}{c}14.84 \\
(2.65)\end{array}$ \\
\cline { 2 - 9 } & Bogra & 380 & 370.08 & $3.95(1.04)$ & $\begin{array}{c}1.82 \\
(0.48)\end{array}$ & $\begin{array}{c}2.93 \\
(0.77)\end{array}$ & $\begin{array}{c}1.22 \\
(0.32)\end{array}$ & $\begin{array}{c}9.92 \\
(2.61)\end{array}$ \\
\cline { 2 - 9 } & Jessore & 420 & 409.96 & $4.54(1.08)$ & $\begin{array}{c}2.14 \\
(0.51)\end{array}$ & $\begin{array}{c}3.36 \\
(0.80)\end{array}$ & $\begin{array}{c}1.34 \\
(0.32)\end{array}$ & $\begin{array}{c}10.04 \\
(2.39)\end{array}$ \\
\cline { 2 - 9 } & All areas & 453.33 & 441.32 & $4.90(1.08)$ & $\begin{array}{c}2.27 \\
(0.50)\end{array}$ & $\begin{array}{c}3.40 \\
(0.75)\end{array}$ & $\begin{array}{c}1.45 \\
(0.32)\end{array}$ & $\begin{array}{c}12.01 \\
(2.65)\end{array}$ \\
\hline
\end{tabular}

Figures inside the parentheses indicate percentage loss of total quantity loss of vegetable.

Table 04. Postharvest loss in brinjal at retail level (Figures in quintals)

\begin{tabular}{|c|l|c|c|c|c|c|c|c|}
\hline \multirow{3}{*}{ Crop } & Districts & $\begin{array}{c}\text { Avg. } \\
\text { quantity } \\
\text { purchase }\end{array}$ & $\begin{array}{c}\text { Avg. } \\
\text { quantity } \\
\text { sold }\end{array}$ & $\begin{array}{c}\text { Grading, } \\
\text { packaging } \\
\text { and loading } \\
\text { loss }\end{array}$ & $\begin{array}{c}\text { Storage } \\
\text { loss }\end{array}$ & $\begin{array}{c}\text { Transportati } \\
\text {-on loss }\end{array}$ & $\begin{array}{c}\text { Selling } \\
\text { loss }\end{array}$ & $\begin{array}{c}\text { Total } \\
\text { loss }\end{array}$ \\
\hline \multirow{3}{*}{ Brinjal } & Norsingdi & 70 & 65.85 & $1.39(1.99)$ & & $0.60(0.85)$ & $\begin{array}{c}2.16 \\
(3.09)\end{array}$ & $\begin{array}{c}4.15 \\
(5.93)\end{array}$ \\
\cline { 2 - 9 } & Bogra & 74 & 69.62 & $1.47(1.98)$ & & $0.67(0.90)$ & $\begin{array}{c}2.26 \\
(3.05)\end{array}$ & $\begin{array}{c}4.38 \\
(5.92)\end{array}$ \\
\cline { 2 - 9 } & Jessore & 76 & 71.44 & $1.50(1.97)$ & & $0.75(0.99)$ & 2.33 & 4.56 \\
& & $73.04)$ & $(6.00)$ \\
\cline { 2 - 9 } & All areas & 73.33 & 68.96 & $1.45(1.98)$ & - & $0.67(0.92)$ & 2.24 & 4.37 \\
$(3.06)$ & $(5.96)$ \\
\hline
\end{tabular}

Figures inside the parentheses indicate percentage loss of total quantity loss of vegetable.

\section{Factors responsible for postharvest losses of brinjal at farm level}

To know the factors responsible of postharvest loss a multiple regression model was carried out. Table 05 represented the factors of brinjal postharvest loss at different levels. It was observed that $64 \%$ variations explained by this model and $\mathrm{F}$ ratio was significant, indicated that regression model was good fit in these case. 
It is clear that in case of brinjal (Table 05), the variables like sale price of brinjal (-2.031), farming experience $(-1.986)$ and transportation dummy $(-0.976)$ were negatively significant indicate that with the increase of sale price $(1 \mathrm{Tk} / \mathrm{kg})$, farming experience (1 year) and transportation facilities, the postharvest loss will be decreased $2.031 \mathrm{~kg}, 1.986 \mathrm{~kg}$, and $0.976 \mathrm{~kg}$ respectively. Total production (0.589) and weather dummy (0.178) had positive and significant relationship with total postharvest losses which indicates that, with the increase of production of brinjal and weather is unfavorable during harvest, postharvest loss will be increased.

Table 05. Estimated values of coefficients and related statistics of multiple linear regression model for postharvest losses of Brinjal at farmer's level

\begin{tabular}{|l|l|l|l|l|}
\hline \multirow{2}{*}{ Regression variable } & Brinjal & \multicolumn{3}{|l|}{} \\
\cline { 2 - 5 } & $\begin{array}{l}\text { Regression } \\
\text { coefficients }\end{array}$ & t-statistics & P-value & $\begin{array}{l}\text { Standard } \\
\text { error }\end{array}$ \\
\hline Intercept & $30.045^{* *}$ & 2.321 & 0.056 & 12.945 \\
\hline Age of the farmer(years) $\mathrm{X}_{1}$ & 6.087 & 1.489 & 0.361 & 4.062 \\
\hline Education (Schooling years) $\mathrm{X}_{2}$ & 3.0125 & 1.520 & 0.894 & 1.981 \\
\hline Farming experience $\mathrm{X}_{3}$ & $-1.986^{* *}$ & 1.981 & 0.071 & 1.003 \\
\hline Total production $\mathrm{X}_{4}$ & $0.589^{* * *}$ & 4.750 & 0.000 & 0.124 \\
\hline Sale price (Tk./kg) $\mathrm{X}_{5}$ & $-2.031^{* *}$ & 1.997 & -0.045 & 1.017 \\
\hline Transportation dummy $\mathrm{X}_{6}$ & $-0.976^{*}$ & 1.513 & -0.074 & 0.645 \\
\hline Weather dummy $\mathrm{X}_{7}$ & $0.178^{*}$ & 0.313 & 0.079 & 0.568 \\
\hline $\mathrm{N}$ & 45 & & & \\
\hline $\mathrm{R}^{2}$ & 0.642 & \multicolumn{4}{|l}{} \\
\hline $\mathrm{F}$ value & $44.679^{* *}$ \\
\hline
\end{tabular}

'***', ‘**' and '*' denote $1 \%, 5 \%$ and $10 \%$ level of significance

Table 06. Respondents' perception on problems of brinjal postharvest operations (Figures in percentage)

\begin{tabular}{|l|c|}
\hline Particulars & Brinjal \\
\hline Problems faced by farmers & 80 \\
\hline 1. Improper handling after harvesting of brinjal & 100 \\
\hline 2. Lack of pre-cooling facilities & 100 \\
\hline 3. Inadequate cold storages & 100 \\
\hline 4. Absence of postharvest treatments & 80 \\
\hline 5. Lack of training and experience & 70 \\
\hline 6. Low market price of brinjal & \\
\hline Problems faced by intermediaries & 58 \\
\hline 1. Unreliable, inefficient and costly transport & 81 \\
\hline 2. Poor packaging & 90 \\
\hline 3. Lack of long time storage facilities & \\
\hline
\end{tabular}

\section{Problems of postharvest operation}

Postharvest operations in the study areas are very traditional method. Traditional postharvest management, improper handling, lack of pre-cooling and storage facilities, poor transportation facilities both farmers and intermediaries level faced by respondents. Detail problems of the farmer and intermediaries' level faced in the study areas are given below:

Table 06 showed that on average 80 percent farmers in all areas reported that improper handling after harvesting of brinjal, $100 \%$ absence of postharvest treatments to reduce the postharvest losses. On average $100 \%$ farmers opinioned that lack of available storage facilities huge quantity of brinjal 
losses every year. Low market price was the serious problems during peak period of harvesting of brinjal in all study areas. Average $70 \%$ farmers mentioned that due to low price huge quantity brinjal loss this year. Average $80 \%$ farmers mentioned that lack of training and experiences for workers were responsible for at harvesting time losses. In marketing level 58\% intermediaries mentioned that unreliable, inefficient and costly transport causes huge quantity brinjal loss. In all study areas, average $70 \%$ intermediaries reported that poor packaging also responsible for vegetable loss. Lacks of storage facilities $90 \%$ traders consider huge quantity brinjal damage every year in study areas.

\section{Conclusion and Recommendations}

Vegetable play a significant role to farmer's income, food and nutritional security, employment to large numbers of people. Estimation of postharvest losses is important as it helps in identifying the causal factors and provides ways and means to reduce the losses. These losses take place at all stages resulting in losses to farmers, deterioration in quality, reduced nutritional value and high costs to consumers. Hence, there is an urgent need to reduce postharvest losses by adopting appropriate policies, technologies and regional cooperation. At farmer level, highest loss occurred in harvesting period because huge quantity of brinjal affected by insect, rotten and unscientific method of harvesting operations. At the retail level, brinjal loss was occurred to during selling time a large volume of product loss for delay selling and spoilage. Farming experience, price of brinjal and transportation dummy had negatively significant effect and total production of brinjal and weather had positively significant effect of postharvest loss at farmer level. Absence of postharvest treatment, lack of storage facilities, and low price of brinjal, poor packaging, and unsuitable transportation facilities were the major problems in study areas faced both farmers and intermediary's level.

The study has suggested that some possible solutions to tackle the problems of postharvest losses:

- harvesting of brinjal at proper maturity stage with appropriate scientific manner

- farmers should apply proper postharvest treatments with scientific method

- care should be taken during harvesting and packaging period of brinjal

- market infrastructure should be developed in terms of quick transportation, proper storage and other physical facilities to reduce postharvest loss brinjal as well as fresh brinjal, and

- adequate training on postharvest activities of vegetable such as harvesting and handling technique should be arranged time to time for the farmers and intermediaries.

\section{References}

[1]. Amiruzzaman, M. (1990). Post-harvest handling and processing of fruits and Brinjal. In 'Kitchan gardening and homestead Productive Activities' (CIRDAP Action Research Series No. 11). Dhaka: Centre on Integrated Rural Development for Asia and the Pacific. p. 22.

[2]. BBS (Bangladesh Bureau of Statistics) (2011). Yearbook of Agricultural Statistics of Bangladesh 2011. Ministry of Planning, Government of the People's Republic of Bangladesh.

[3]. FAO (2003). Diet, nutrition and the preservation of chronic disease. Report of a joint FAO/WHO, Expert Consultation, WHO Technical Report Series 916, Geneva.

[4]. Hassan, M. K. (2010). Final report-postharvest loss assessment: a study to formulate policy for loss reduction of fruits and brinjal and socio-economic uplift of the stake holders (Funded by USAID and EC and Jointly Implemented by FAO and FPMU of MoFDM). p. 189.

[5]. Kader, A. A. (1992). Postharvest technology of horticultural crops (2nd ed.), Publication No. 3311. Division of Agricultural and Natural Resource, University of California. 


\section{How to cite this article?}

\section{APA (American Psychological Association)}

Kaysar, M. I., Mia, M. S., Islam, M. S. \& Kausar, A. K. M. G. (2016). Postharvest loss assessment of brinjal in some selected areas of Bangladesh. International Journal of Business, Management and Social Research, 02(02), 118-124.

\section{MLA (Modern Language Association)}

Kaysar, M. I., Mia, M. S., Islam, M. S. \& Kausar, A. K. M. G. "Postharvest loss assessment of brinjal in some selected areas of Bangladesh." International Journal of Business, Management and Social Research, 02.02 (2016): 118-124.

\section{Chicago/Turabian}

Kaysar, M. I., Mia, M. S., Islam, M. S. \& Kausar, A. K. M. G. Postharvest loss assessment of brinjal in some selected areas of Bangladesh. International Journal of Business, Management and Social Research, 02, no. 02 (2016): 118-124. 